\title{
PERBEDAAN TEKNIK MORDANTING TERHADAP HASIL PENCELUPAN BAHAN KATUN PRIMISIMA MENGGUNAKAN WARNA ALAM EKSTRAK DAUN LAMTORO (Leucaena leucocephala) DENGAN MORDAN KAPUR SIRIH
}

\author{
Khusnia Zulikah ${ }^{1 *}$, Adriani ${ }^{2 *}$ \\ Program Studi Pendidikan Kesejahteraan Keluarga Jurusan Ilmu Kesejahteraan Keluarga \\ Fakultas Pariwisata dan Perhotelan \\ Universitas Negeri Padang \\ Jl. Prof. Dr. Hamta, Air Tawar Padang, Kel. Air Tawar Barat, Kec. Padang Utara, Kota Padang, Kode Pos 25171 \\ Sumatera Barat. Indonesia \\ Email:khusniazulikah@gmail.com
}

\begin{abstract}
Abstrak
Penelitian ini bertujuan untuk mendiskripsikan: 1) nama warna (hue) 2) gelap terang warna (value) 3) kerataan warna dan 4) perbedaan yang dihasilkan pada pencelupan bahan mori primisima menggunakan warna alam ekstrak daun lamtoro (leucaena leucocephala) dengan mordan kapur sirih sirih. Penelitian ini merupakan penelitian Eksperiment. Data yang digunakan adalah data primer yang bersumber dari 15 orang panelis, kemudian data yang terkumpul diolah dan dianalisis dengan bantuan SPSS (Statistikal Product and Service Solution) versi 16.0 dengan memakai rumus uji friedman $K$ related sample. Warna yang dihasilkan dengan teknik Pra-mordanting adalah Golden Sundance dengan volume terang dan kerataan warna sangat rata, Mordanting simultan (meta) adalah Golden Sundance dengan volume cukup terang dan kerataan warna cukup rata dan dengan teknik postMordanting adalah Golden rod dengan volume kurang terang dan kerataan warna sangat rata. Hasil analisis data yang diperoleh dari uji Friedman K-relatif sample untuk gelap terang warna (value) data yang diperoleh signifikansi sebesar $0,000<0,05=$ Ho ditolak, artinya terdapat pengaruh yang signifikan terhadap gelap terang warna (value) akibat perbedaan teknik mordanting. Pada kerataan warna data yang diperoleh adalah $0,001<0,05=$ Ho ditolak. Artinya bahwa terdapat pengaruh yang signifikan akibat penggunaan teknik mordanting.
\end{abstract}

Kata Kunci: mordanting, lamtoro, kapur sirih.

\begin{abstract}
This study aims to describe: 1) the name of color (hue) 2) the darkness of color (value) 3) the uniformity of color and 4) the differences produced in dyeing the material of primisima using natural color leaves extract of lamtoro (leucaena leucocephala) with mordan lime betel betel This research is a Experiment. The data used are primary data sourced from 15 panelists, then the collected data is processed and analyzed with the help of SPSS (Statistikal Product and Service Solution) version 16.0 using the $\mathrm{K}$ related sample friedman test formula. The color produced by the Pre-mordanting technique is the Golden Sundance with bright volume and very flat evenness, Mordanting simultan (meta) is a Golden Sundance with a fairly bright volume and fairly flat evenness and with post-Mordanting technique is a Golden rod with less bright volume and the color evenness is very flat. The results of data analysis obtained from the Friedman $K$-relative sample for dark colors (value) data obtained significance 0,000 $<0.05=$ Ho rejected, meaning that there is a significant effect on dark bright color (value) due to differences in mordanting techniques. On the color flatness of the data obtained $0.001<0.05=H o$ is rejected. This means that there is a significant effect due to the use of mordanting techniques.
\end{abstract}

Keywords: mordanting, lamtoro, betel lim.

\section{PENDAHULUAN}

Penggunaan zat warna mempunyai kelebihan dan keuntungan. Penggunaan zat warna sintetis memiliki kelemahan yakni limbah pembuatan zat warna sintetis tersebut dapat menimbulkan pencemaran lingkungan, serta berakibat buruk pada tubuh manusia. Oleh karena itu, pemanfaatan zat warna alam (ZWA) sebagai alternatif untuk mengurangi dampak terhadap penggunaan zat warna sintetis. Diantaranya pewarna alam ini ramah bagi kesehatan, bebas zat kimia, mudah didapatkan dan juga hemat biaya, karena kandungan komponen alamiahnya tidak mempunyai beban pencemaran, mudah terurai secara biologis, proses pewarnaanya menghasilkan limbah cair yang 


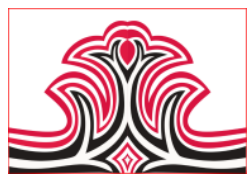

tidak beracun dan bahan bakunya mudah didapatkan dilingkungan sekitar kita.

ZWA dapat diperoleh dari daun, diantaranya daun ketepeng, daun jambu, daun jati, daun indigofera, daun kepel daun pacar air, daun alpukat daun orangaring (Tim Sanggar Batik Barcobe, 2010: 108). Proses penemuan zat warna alam dari suatu tanaman merupakan suatu yang tidak mudah dan membutuhkan waktu yang lama. Salah satu tanaman yang dapat dijadikan sebagai bahan pewarna alami adalah daun Lamtoro (Leucaena leucocephala Lam). Menurut Jayanegara (2008:44) "Daun lamtoro (Leguminosea) sebagai zat organik tidak jenuh banyak mengandung senyawa fenolik dalam konsentrasi tinggi, khususnya tanin dan mimosin. Tanin dapat dimanfaatkan untuk pewarna yang dapat menimbulkan warna”. Disini peneliti menggunakan daun yang sudah bewarna hijau tua, karena daun yang sudah agak tua banyak mengandung zat tanin dibandingkan daun bagian pucuk atau atas.

Selain larutan ZWA, pewarna bahan tekstil ini juga dipengaruhi oleh bahan tekstil yang digunakan. Dalam penelitian ini, bahan tekstil yang digunakan adalah katun primisima. Menurut Hartanto (1980: 10) "Katun primisima (mori primisima) merupakan salah satu jenis kain yang berasal dari serat selulosa atau tumbuh-tumbuhan". Hal ini dilakukan karena kain mori primisima merupakan kain yang baik jika digunakan untuk pencelupan, memiliki kualitas yang baik dan tidak ada cacat tenun.

Dalam pencelupan ZWA untuk memperoleh hasil yang lebih baik kita memerlukan mordan. Menurut Fitrihana (2007: 5) "Mordan adalah zat yang digunakan untuk membantu meningkatkan afinitas zat warna alam terhadap serat, sehingga zat mordan adalah zat khusus yang digunakan dalam pencelupan yang dapat meningkatkan daya ikat zat warna terhadap bahan". Teknik yang digunakan adalah teknik mordanting Menurut Fitrihana (2007:137) "Mordanting adalah proses untuk meningkatkan daya tarik zat warna alam terhadap bahan tekstil serta berguna untuk menghasilkan kerataan ketajaman warna yang baik".

Hasil pencelupan ekstrak daun lamtoro setelah dicelupkan pada mordan kapur sirih menghasilkan warna Golden Sundance. Berdasarkan uraian diatas penulis sangat tertarik melakukan penelitan dengan judul "Perbedaan Teknik Mordanting Terhadap Hasil Pencelupan Bahan Katun Primissima Menggunakan
Gorga Jurnal Seni Rupa

Volume 08 Nomor 01 Januari-Juni 2019

p-ISSN: 2301-5942 | e-ISSN: 2580-2380

Warna Alam Ekstrak Daun Lamtoro (Leucaena Leucocephala) Dengan Mordan Kapur Sirih ".

Penelitian ini bertujuan untuk mendeskripsikan : 1) nama warna (hue), 2) gelap terang warna (value), 3) kerataan warna 4) perbedaan yang dihasilkan pada pencelupan bahan mori primisima menggunakan zat warna alam ekstrak daun lamtoro dengan mordan kapur, tanpa mordan, teknik pra-mordanting, metamordanting, post-mordanting.

\section{KAJIAN TEORI}

Sebelum digunakan bahan tekstil telah mengalami bermacam-macam pengolahan yang bertujuan untuk meningkatan mutu bahan tersebut. Salah satu cara pengolahan bahan tekstil tersebut adalah dengan cara penyempurnaan ( pencelupan ). Menurut Chatib (1981: 1) "pencelupan yaitu suatu proses pemberian warna pada bahan secara merata dengan bermacammacam zat warna dan sifat permanen". Dalam proses pencelupan terdapat suatu proses penyerapan zat warna kedalam serat yang disebut dengan reaksi eksotermik (mengeluarkan panas) dan keseimbangan. Pada proses pencelupan terjadi tiga peristiwa penting yaitu migrasi, adsorpsi, dan difusi. Pencelupan ZWA diperoleh dari hasil ekstraksi bagian tumbuhan yang memiliki kandungan pigmen sebagai penimbul warna salah satunya menggunakan daun lamtoro.

Menurut Jayanegara (2008:44) "Daun lamtoro sebagai zat organik tidak jenuh banyk mengandung senyawa fenolik dalam konsentrasi tingggi khususnya tanin dan mimosin seperti halnya daun lamtoro". Tanin merupakan suatu senyawa polifenol yang berasal dari tumbuhan, berasa pahit dan kelat, yang bereaksi dengan menggumpulkan protein atau berbagai senyawa organik lainnya termasuk asam amino dan alkaloid.

Selain larutan zat warna alam, pewarna bahan tekstil ini juga dipengaruhi oleh bahan tekstil yang digunakan. Menururt Susanto: 1978: 53): Kain mori dari katun lebih umum digunakan dalam pembatikan. Berdasarkan kehalusannya, kain mori dari katun dibedakan menjadi 4 golongan:

1. Mori Primissima adalah golongan mori yang paling halus. Dibuat batik secara batik tulis, jarang dikerjakan secara batik cap.

2. Mori Prima adalah golongan mori halus yang kedua sesudah mori primissima.Mori golongan prima dapat untuk batik halus dan dapat pula untuk batik cap. 


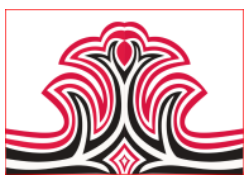

3. Mori Biru adalah golongan kualitas ketiga setelah primissima dan prima.Mori biru biasanya untuk membuat batik kasar dan sedang.

4. Mori Blaco adalah golongan kain yang paling rendah kualitasnya. Mori blaco disebut pula golongan mori merah atau kain greykarena biasanya dijual dipasaran dalam keadaan grey atau belum diputihkan.

Kain mori merupakan kain yang berasal dari serat alam yaitu kapas dan kain tersebut merupankan jenis kain mori dengan kualitas tinggi dibandingakan dengan kedua jenis kain mori lainnya. Dalam pencelupan ZWA, untuk memperoleh hasil yang lebih baik kita memerlukan zat pembantu yaitu mordan. Tujuannya adalah untuk meningkatkan nilai warna. Mordan yang digunakan adalah kapur sirih.

Menurut Budiyono, (2008: 72) “Kapur akan menghasilkan warna menengah atau kecoklatan pada pewarnaan alam". Sifat kapur sirih yang dapat mengikat asam amino yang terkandung pada daun lamtoro sehingga dapat menghasilkan warna yang baik.

Pada pencelupan ZWA untuk mendapatkan hasil yang sempurna selain mordan dan bahan yang digunakan teknik pemberian mordan atau disebut teknik mordanting juga berpengaruh terhadap hasil pencelupan berupa warna dan gelap terang warna.

Menurut Fitrihana (2007:137) "Mordanting adalah proses untuk meningkatkan daya tarik zat warna alam terhadap bahan tekstil serta berguna untuk menghasilkan kerataan ketajaman warna yang baik. Menurut Djufri dan Elsa (2015:7) "Mordanting dapat dilakukan dengan tiga cara 1. cara Mordanting pendahuluan (Pra-Mordanting), 2. cara Mordanting simultan (meta-chrom, mono-chom), 3. cara Mordanting akhir (post-chrom)'”.

\section{METODE PENELITIAN}

Penelitian ini merupakan jenis penelitian experimen. Menurut Sugiyono (2010:72) "Penelitian eksperimen adalah metode penelitian yang digunakan untuk mencari perbedaan perlakuan tertentu terhadap yang lain dalam kondisi yang terkendalikan". Objek penelitian adalah mordanting dengan mordan kapur sirih pada bahan mori primisima. Yang dicelup dengan warna alam daun lamtoro (Leucaena leucocephala), secara pra mordanting, metamordanting (simultan), dan post-mordanting. Menggunakan vlot 1:10 untuk mengetahui warna (hue) gelap terang warna (value), dan kerataan warna
Gorga Jurnal Seni Rupa

Volume 08 Nomor 01 Januari-Juni 2019

p-ISSN: 2301-5942 | e-ISSN: 2580-2380

menggunakan zat warna alam, peralatan, serta suhu yang sama.

Sumber data dalam penelitian ini yaitu hasil ekperimen yang dijawab oleh panelis dari kuisioner yang disebarkan. Jumlah 15 orang panelis, yaitu 3 orang dosen Fakultas Pariwisata Dan Perhotelan sebagai orang yang memahami warna dan tekstil, 12 orang mahasiswa PKK sebagai panel terlatih yang telah lulus mata kuliah pengetahuan tekstil dan analisis tekstil.

Penelitian menggunakan jenis data primer. Data yang terkumpul dan diolah dengan SPSS (Statistikal Product and Service Solution), bertujuan untuk melihat pengaruh yang dihasilkan pada pencelupan bahan mori primisima menggunakan estrak daun lamtoro dengan mordan kapur sirih teknik mordanting menggunakan Rumus uji friedman K-related sample.

\section{HASIL DAN PEMBAHASAN \\ 1.Hasil}

Uji ini dilakukan jika asumsi-asumsi dalam statistic parametris tidak terpenuhi atau karena sampel yang terlalu sedikit. Pengujian ini dilakukan melalui aplikasi SPSS (Statistical Product and Service Solution) versi 16.0. Data penelitian terhadap 15 orang panelis, diperoleh nilai maen sebagai herikut tanpa mordan mendapat rata-rata 1,26, den $\quad 205$ ramordanting nilai rata-ratanya adalah _,_., .....gan teknik simultan (meta)-mordanting memperoleh nilai rata-rata 2,26, sedangkan nilai rata-rata postmordanting adalah 2,40.

Tabel 1. Hasil Uji Friedman K-Related Sample Gelap Terang Warna (Value) Pencelupan Bahan Katun Primissima Menggunkan Ekstrak Daun Lamtoro (Leucaena Leucocephala) Menggunakan Teknik Mordanting.

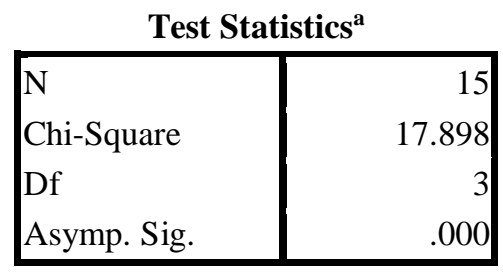

a. Friedman Test

Pada tabel 1 di atas dapat dijelaskan bahwa uji Friedman K-Related Sample gelap terang warna (value) diperoleh nilai signifikansi sebesar 0,000 yang lebih kecil dari taraf signifikansi 0,05 atau $0,000<$ 0,05 . Artinya terdapat pengaruh penggunaan teknik mordanting terhadap gelap terang warna dalam 
pencelupan bahan katun primissima menggunakan ekstrak daun lamtoro (Leucaena Leucocephala).

Dari data penelitian terdapat 15 orang panelis, diperoleh nilai maen sebagai berikut: tanpa mordan rata-rata 1,66 , dengan teknik pra-mordnating 1,86 , dengan teknik simultan-mordanting rata-ratanya adalah 2,26, sedangkan rata-rata untuk teknik postmordanting adalah 1,06.

Tabel 2. Hasil Uji Friedman K-Related Sample Gelap Terang Warna (Value) Pencelupan Bahan Katun Primissima Menggunkan Ekstrak Daun Lamtoro (Leucaena Leucocephala) Tanpa Mordan dan Menggunakan Teknik Pra, Simultan (Meta)- Dan PostMordanting

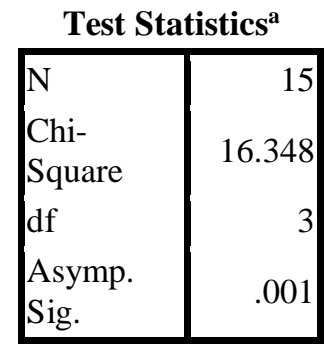

a. Friedman Test

Pada tabel 2 di atas dapat dijelaskan bahwa uji Friedman K-Related Sample kerataan warna pada pencelupan bahan katun primissima menggunakan ekstrak daun lamtoro (Leucaena Leucocephala) tanpa mordan, pra-mordanting, simultan (meta)-mordanting dan post-mordanting diperoleh nilai signifikansi sebesar 0,001 yang lebih kecil dari taraf signifikansi 0,05 atau $0,001<0,05$. Artinya terdapat perbedaan yang signifikan dengan teknik mordanting pada pencelupan bahan katun primissima menggunakan ekstrak daun lamtoro (Leucaena Leucocephala) terhadap kerataan warna.

\section{Pembahasan}

Warna yang dihasilkan dalam proses pencelupan dilihat menggunakan aplikasi Colorblind Assistand pada pencelupan bahan katun primissima menggunakan ekstrak daun lamtoro (Leucaena Leucocephala) tanpa mordan menghasilkan nama warna adalah Wheat light Brown kode warna \#F3D7A8 memiliki nilai R (Red) 243 G (Green) 215 dan B (Blue) 168.

Teknik pra-mordanting menghasilkan nama warna (hue) Golden Sundance kode warna \#D2964E memiliki nilai R (Red) 210 G (Green) 150 dan B (Blue) 078. Selanjutnya teknik simultan (meta) mordanting menghasilkan nama warna (hue) adalah Golden Sundance kode warna \#D69D58 memiliki nilai R (Red) 214 G (Green) 157 dan B (Blue) 088.
Gorga Jurnal Seni Rupa

Volume 08 Nomor 01 Januari-Juni 2019

p-ISSN: 2301-5942 | e-ISSN: 2580-2380

Sedangkan teknik post-mordanting menghasilkan nama warna (hue) Golden rod kode warna \#DF9F43 memiliki nilai R (Red) 223 G (Green) 159 dan B (Blue) 067

Pada pencelupan warna ekstrak daun lamtoro (Leucaena Leucocephala) terhadap bahan katun primisima menggunakan teknik mordanting gelap terang warnanya bertingkat, tanpa mordan memperoleh warna yang sangat terang, pramordanting memperoleh warna terang, simultan (meta)-mordanting memperoleh warna cukup terang, sedangkan post-mordanting memperoleh warna yang kurang terang atau gelap. Dalam penelitian ini ekstrak daun lamtoro teknik post-mordanting mengalami penyerapan lebih sempurna karena menghasilkan warna yang gelap atau lebih kental.

Berdasarkan hasil pencelupan bahan katun primisima menggunakan ekstrak daun lamtoro (Leucaena Leucocephala) tanpa menggunkan mordan 66,67\% panelis menyatakan sangat rata, teknik pramordanting $60,00 \%$ panelis menyatakan sangat rata, teknik simultan (meta)-mordanting 53,33\% panelis menyatakan cukup rata dan teknik post-mordanting 93,33\% panelis menyatakan sangat rata. Artinya perbedaan kerataan warna tanpa mordan, pramordanting, simultan (meta)-mordanting dan postmordanting menghasilkan kerataan warna kategori sangat rata.

Berdasarkan analisis yang diperoleh dari uji Friedman $K$-relatif sample untuk gelap terang warna (value) data yang diperoleh signifikansi sebesar 0,000 yang lebih kecil dari taraf signifikansi 0,05 atau $0,000<0,05=$ Ho ditolak. Dari penjelasn tersebut dapat disimpulkan bahwa terdapat pengaruh yang signifikan terhadap gelap terang warna (value) akibat pengaruh menggunakan teknik mordanting pada pencelpan bahan katun primisima dengan ekstrak daun lamtoro (Leucaena Leucocephala).

Analisis yang diperoleh dari uji Friedman K-relatif sample untuk kerataan warna data yang diperoleh adalah 0,001 yang lebih kecil dari taraf signifikansi 0,05 atau $0,001<0,05=$ Ho ditolak. Artinya bahwa terdapat pengaruh yang signifikan akibat penggunaan teknik mordanting terhadap kerataan warna terhadap pencelupan bahan katun primisima menggunakan ekstrak daun lamtoro (Leucaena Leucocephala). 


\section{KESIMPULAN DAN SARAN}

\section{Kesimpulan}

Nama warna pada pencelupan bahan katun primisima dengan ekstrak daun lamtoro (Leucaena Leucocephala) tanpa menggunakan mordan menghasilkan warna Wheat light Brown kode warna \#F3D7A8, teknik pra-mordanting maka menghasilkan nama warna Golden Sundance kode warna \#D2964E, meta-mordanting menghasilkan nama warna Golden Sundance kode warna \#D69D58 dan teknik postmordanting menghasilkan nama warna (hue) Golden rod kode warna \#DF9F43.

Berdasarkan hasil pencelupan bahan katun primisima menggunakan ekstrak daun lamtoro (Leucaena Leucocephala) tanpa menggunkan mordan kapur sirih $80 \%$ panelis menyatakan sangat terang, teknik pramordanting $53,33 \%$ panelis menyatakan terang, teknik meta-mordanting $60 \%$ panelis menyatakan cukup terang, dan dengan teknik post-mordanting 53,33\% panelis menyatakan kurang terang.

Berdasarkan hasil pencelupan bahan katun primisima menggunakan ekstrak daun lamtoro (Leucaena Leucocephala) tanpa menggunakan mordan 66,67\% panelis menyatakan warna sangat rata, teknik pramordanting $60 \%$ panelis menyatakan sangat rata, teknik meta-mordanting $53,33 \%$ panelis menyatakan cukup rata, dan dengan teknik post-mordanting 93,33\% panelis menyatakan sangat rata.

Berdasarkan analisis yang diperoleh dari uji Friedman $K$-relatif sample untuk gelap terang warna (value) data yang diperoleh adalah 0,000 yang lebih kecil dari taraf signifikansi 0,05 atau $0,000<0,05$ yang artinya Ho ditolak. Dari penjelasan diatas dapat diambil kesimpulan bahwa terdapat perbedaan yang signifikan terhadap gelap terang warna (value) pencelupan bahan katun primisima menggunakan ekstrak daun lamtoro (Leucaena Leucocephala) dengan mordan kapur sirih pada teknik pra-mordanting, simultan (meta)mordanting dan post-mordanting.

Analisis yang diperoleh dari uji Friedman $K$-relatif sample untuk kerataan warna data yang diperoleh adalah 0,001 lebih besar kecil dari taraf signifikansi 0,05 atau $0,001<0,05$ yang artinya Ho ditolak. Dari penjelasan diatas dapat diambil kesimpulan bahwa terdapat perbedaan yang signifkan dari penggunaan teknik pra-mordanting, simultan (meta)-mordanting dan post-mordanting terhadap kerataan warna dalam pencelupan bahan katun primisima menggunakan ekstrak daun lamtoro (Leucaena Leucocephala) dengan mordan kapur sirih.

\section{Saran}

Bagi mahasiswa tata busana sebagai bahan memperluas pengetahuan dan wawasan mengenai ilmu tekstil tentang pencelupan menggunakan zat warna alam khususnya daun Lamtoro (Leucaena Leucocephala).

Bagi mahasiswa jurusan Ilmu Kesejahteraan Keluarga (Tata Busana) agar dapat melakukan penelitian lebih lanjut tentang eksperimen pewarnaan ekstrak zat warna alam karena masih banyak sumber daya alam yang dapat menghasilkan warna-warna yang berbeda.

Bagi masyarakat dapat memanfaatkan daun lamtoro (Leucaena Leucocephala) sebagai pewarna tekstil yang ramah lingkungan sebagai pengganti zat warna sintetis.

\section{DAFTAR RUJUKAN}

Budiyono. (2008). “Kriya Tekstil Jilid 1". Jakarta: Direktorat Pembinaan Sekolah Menengah Kejuruan.

Chatib, Winarni. (1981). "Teori Penyempurnaan Tekstil”. Jakarta: Direktorat Jendral Pendidikan Dasar Dan Menengah.

Elsa. (2015). Perbedaan Teknik Mordanting Terhadap Hasil Pencelupan Zat Warna Alam Ekstrak Daun Keladi Hias (Philodendron) Dengan Mordan Air Tapai Pada Bahan Sutera. Padang: Jurnal Jurusan IKK Fakultas Pariwisata Dan Perhotelan, Universitas Negeri Padang.

Fitrihana, Noor. (2007). “Jurnal Sekilas Tentang Warna Alam Untuk Tekstil “. www.batikjogya. Wordpress.com diakses 26 januari 2019

Hartanto, Sugiarto. (1980). Teknologi Tekstil. Jakarta: PT. Pradnya Paramita.

Jayanegara. (2008). "Penentuan Aktivitas Biologis Tannin Beberapa Hijauan Secara In Vitro Menggunakan ' Hohenheim Gas Test' Dengan Polietilen Glikol Sebagai Determinan”. Med. Pet.31:44-52.

Susanto S.K, Sewan. (1978). Seni Kerajinan Batik Indonesia. Yogyakarta: Balai Penelitian dan Kerajinan Pendidikan Industri, Departemen Perindustrian.

Sugiyono. (2010). “Metode Penelitian Kuantitatif Kualitatif dan $R \& D$ ”. Bandung: Alfabeta.

Tim Sanggar Batik Barcode. (2010). “Batik”. Jakarta: Niaga Swadaya. 